\title{
Zeolitic volcanic tuffs from Măcicaş (Cluj County), natural raw materials used for $\mathrm{NH}^{4+}$ removal from wastewaters
}

\author{
Horea BEDELEAN1*, Maria STANCA², Andrada MĂICĂNEANU² \& Silvia BURCĂ² \\ ${ }^{1}$ Department of Geology, "Babeş-Bolyai” University, 1 Kogălniceanu, 400084 Cluj Napoca, Romania \\ ${ }^{2}$ Department of Chemical Technology, "Babeş-Bolyai” University, 11 Arany Janos, 400028 Cluj Napoca, Romania
}

Received July 2005; accepted March 2006

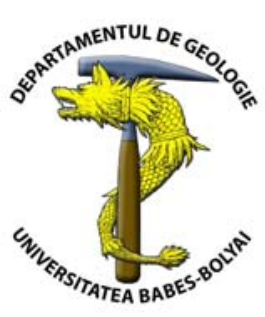

\begin{abstract}
Volcanic tuffs out cropping in Măcicaş area (Cluj County) have been investigated and tested for their ammonium removal capacity. The zeolitic volcanic tuffs from Măcicaş are mainly represented by vitric and vitric crystal tuffs. In this region, significant amounts of volcanic glass in the pyroclastic sequence have been replaced by zeolites (between $50-80 \%$ ). The main zeolite species identified in volcanic tuffs from Măcicaş is clinoptilolite and subordinately mordenite. The zeolitic tuff samples considered in zeolitic sodium form (labeled $\mathrm{M} 1-\mathrm{Na}$ and $\mathrm{M} 2-\mathrm{Na}$ ) are tested in ammonium removal experiments. The ammonium ions were completely removed from $0.0716 \mathrm{~g} / \mathrm{dm}^{3} \mathrm{NH}_{4}{ }^{+}$solution onto $10 \mathrm{~g}$ of zeolitic material in static regime. In dynamic regime, the ammonium ions were completely removed after $250 \mathrm{ml}$ and $500 \mathrm{ml}$ solution passed on M1-Na and M2-Na sample respectively. Also the zeolite exhaustion takes place after more than $1500 \mathrm{ml}$ solution is processed in both cases. The ionic exchange properties suggest that the zeolitic tuff of the Măcicaş region can be used as a final stage (following the biological process) in wastewater treatment plants in order to assure compliance with environmental standards.
\end{abstract}

Key words: natural zeolites, clinoptilolite, volcanic tuffs, Măcicaş, Cluj County, wastewaters, ammonium, ionic exchange

\section{INTRODUCTION}

Zeolites are a group of hydrated aluminum-silicates of the alkali or alkaline earth metals (sodium, potassium, magnesium, calcium). Zeolites have a three-dimensional crystalline framework of tetrahedral silica or alumina anions strongly bonded at all corners and they contain channels filled with water and exchangeable cations.

The structure is suitable for ion exchange due to isomorphous replacement of $\mathrm{Al}^{3+}$ with $\mathrm{Si}^{4+}$ in the structure, giving rise to a deficiency of positive charge in the framework. This is balanced by mono and divalent exchangeable cations such as $\mathrm{Na}^{+}, \mathrm{Ca}^{2+}, \mathrm{K}^{+}$and $\mathrm{Mg}^{2+}$. These cations are coordinated with the defined number of water molecules, and located on specific sites in framework channels (Perić et al., 2004; Cakicioglu-Ozkan and Ulku, 2005). The main consequence of this structure type is represented by the reversibility of the hydration and cation exchange processes that preserve the original network. Thus, they present specific properties (e.g., adsorbtion-desorbtion capacity, ion exchange capacity, catalytic properties), which confer to this group of minerals important and diverse possibilities of usage.

Zeolites - both natural and synthetic, may be used as ionic or molecular filters due to their particular crystal structure of a tectosilicate-type, characterized by pores with larger sizes than those of the ions (molecules) that pass through. Many types of rocks can contain usually small amount of zeolites but the main rock-type containing such minerals is the zeolitic volcanic tuff. Zeolites may form in magmatic, metamorphic and sedimentary rocks. In the sedimentary deposits, five species are present more frequently: analcime, clinoptilolite, heulandite, laumontite and phillipsite. The volcanoclastic deposits contain the largest concentrations of zeolites, which result from the transformation of magmatic products such as volcanic glass and primary aluminum-silicate minerals (Hay and Sheppard, 2001).

The sedimentary zeolitic rocks from Romania are represented by Tertiary volcanic tuffs dominated by the presence of clinoptilolite.

Clinoptilolite is a hydrated alumina-silicate member of the heulandite group and is one of the more useful natural zeolites. Heulandite group zeolites, including mineral clinoptilolite and heulandite and their synthetic analogues, have the same framework topology (structure code HEU) characterized by infinite three-dimensional frameworks of aluminum, silicon and oxygen. According to Coombs et al. (1997), the distinction between the clinoptilolite and the heulandite is based on the $\mathrm{Si} / \mathrm{Al}$ ratio, i.e., clinoptilolite if $\mathrm{Si} / \mathrm{Al}>4$ and heulandite if $\mathrm{Si} / \mathrm{Al}<4$. The chemistry of these two species varies almost continuously between (Bish and Boak, 2001):

$\left(\mathrm{Na}, \mathrm{K}, \mathrm{Ca}_{0.5}\right)_{10}\left(\mathrm{Al}_{10} \mathrm{Si}_{26} \mathrm{O}_{72}\right) \cdot 24 \mathrm{H}_{2} \mathrm{O}$ (heulandite, $\mathrm{Si} / \mathrm{Al}=2.6$ ) $\left(\mathrm{Na}, \mathrm{K}, \mathrm{Ca}_{0.5}\right)_{5.4}\left(\mathrm{Al}_{5.4} \mathrm{Si}_{30.6} \mathrm{O}_{72}\right) \cdot 20 \mathrm{H}_{2} \mathrm{O}$ (clinoptilolite, $\mathrm{Si} / \mathrm{Al}=5.7$ )

Clinoptilolite is a natural zeolite that is widespread in many countries of the world. Its cation exchange and 
adsorption properties make clinoptilolite-bearing rocks of great technological interest (Cerri et al., 2002). Applications for clinoptilolite-bearing rocks include use as additives to cement, in the deodorization of ammonia-polluted environments (Mumpton, 1996), in the treatment of municipal and industrial wastewaters (Pansini, 1996), and in the preparation of lightweight aggregates (Kazantseva et al., 1997). Clinoptilolite bearing materials are primarily used to remove $\mathrm{NH}^{4+}$ from municipal wastewaters by cation exchange processes (Pansini, 1996). These applications are based on the high selectivity that Na-clinoptilolite displays for $\mathrm{NH}^{4+}$ (Collela, 1996).

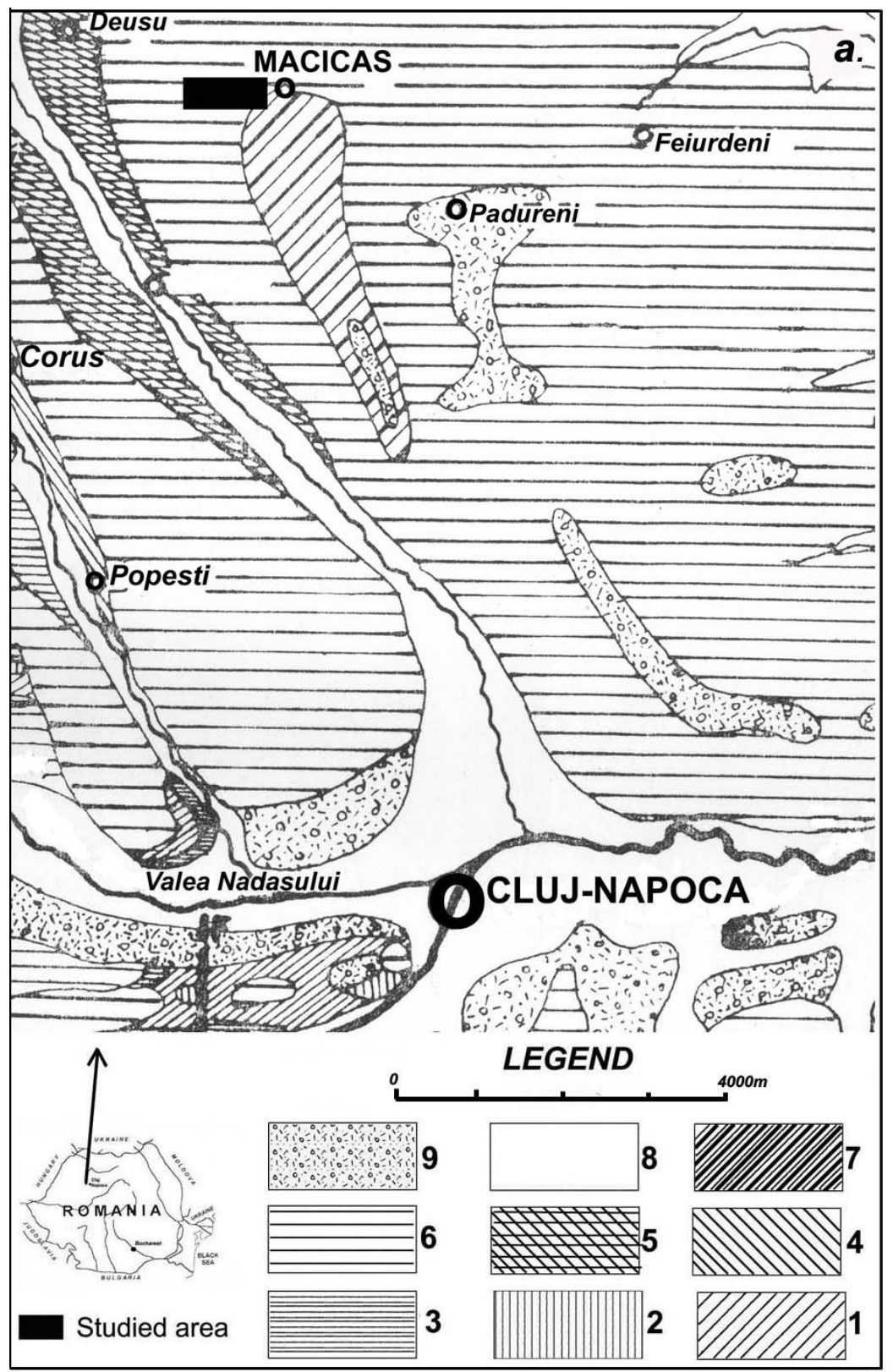

b.

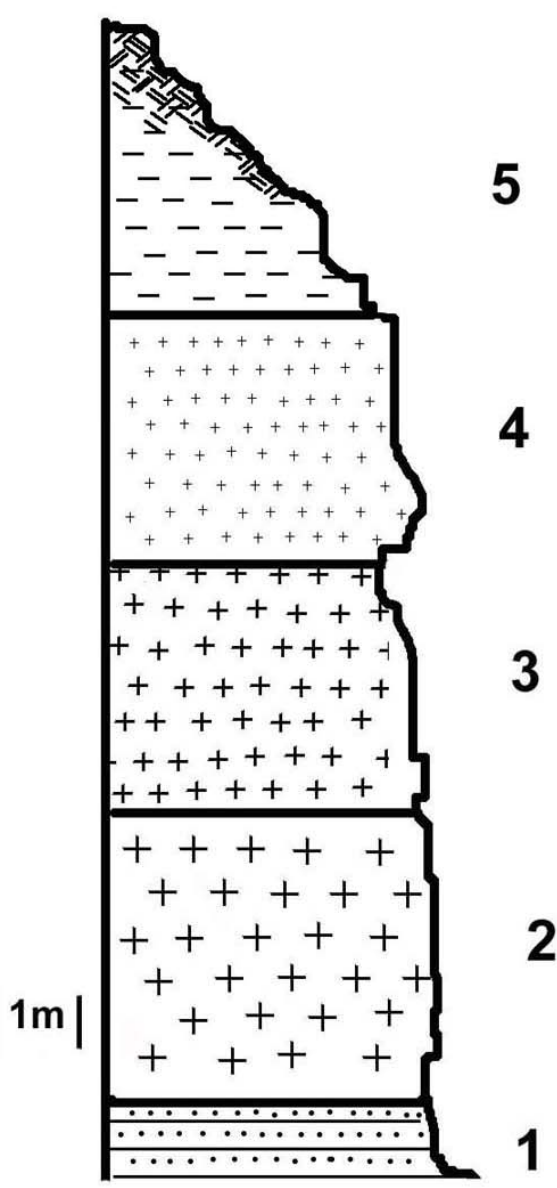

Fig. 1 (a) Geological sketch of the Măcicaş area, Cluj County (modified after Meszaros and Nicorici, 1976).

1- Moigrad Formation+Dâncu Formation (Rupelian); 2- Gruia Sandstone+Var Sandstone (Rupelian);

3- Cuzăplac Formation+Cubleșu Formation (Egerian); 4-Coruş Formation+Chechiş Formation (Eggenburgian);

5- Hida Formation (Ottangian); 6- Badenian (with Dej Tuff Complex); 7-Sarmatian; 8-Alluvium; 9-Terraces of Someşul Mic River.

(b) Lithologic profile of the tuffs from Măcicaş, Cluj County (modified after Răcătăianu et al., 1991).

1- yellowish coarse sandstones; 2- compact, coarse grained, macroporous tuff (sample M2); 3- volcanic tuff with a medium porosity (sample M1); 4-fine grained, microporous, white-greenish volcanic tuff; 5- clay, vegetal soil.

Clinoptilolite is well suited for these applications because of its large amount of pore space and ionic exchange capacity, and because of its high resistance to extreme temperatures and chemically neutral basic structure. $\mathrm{NH}_{4}{ }^{+}$and $\mathrm{NH}_{3}$, forms of inorganic nitrogen, are some of the most common water pollutants. Ammonium is usually present in untreated sewage, industrial wastewater discharges (quench waters at coking plants, gasworks sites), and landfill leachates (fertilizer use, contaminated land) in concentrations ranging from 1 to $7000 \mathrm{mg} / \mathrm{dm}^{3}$ (Buss et al., 2004). Due to the fact that in certain conditions it is a relatively mobile contaminant and considering the wide domain of concentrations, ammonium is considered a key contaminant in risk assessment.

In drinking water treatment, for example, $\mathrm{NH}_{4}^{+}$can reduce disinfection efficiency, lead to nitrite formation, and cause taste and odor problems (Buss et al., 2004). In sewage treatment units, ammonium ions are first transformed during 
the nitrification process (biological oxidation), followed by the denitrification process. When $\mathrm{NH}_{4}{ }^{+}$concentration is too high, alternative methods for removal are considered. Ionic exchange process on synthetic (Dowex 50Wx8, Purolite MN500) (Jorgensen and Weatherley, 2003) and natural exchangers - mineral deposits from Mexico (Levya-Ramos et al., 2004), Chilean zeolite (Englert and Rubio, 2005), Turkish zeolite (Sarioglu, 2005), New Zeeland clinoptilolite and mordenite (Weatherley and Miladinovic, 2004), Croatian zeolite (Farkas et al., 2005), permeable reactive barriers containing clinoptilolite (Park et al., 2002), Italian clinoptilolite (Langella et al., 2000) - was widely studied. Baykal Beler and Guven (1998) and Baykal Beler (1998) proposed the ionic exchange using clinoptilolite for the removal of peak concentrations of ammonia from domestic wastewater as a second stage, by itself or in combination with sand filters or burned clay. They found that all combinations studied are successful in the removal of peak concentrations of ammonia, and hence can be used as a polishing unit (Baykal Beler and Guven, 1998; Baykal Beler, 1998).

In order to test the similar natural materials, our study concerned the volcanic tuffs cropping out in Măcicaş area (Cluj County).

\section{MATERIALS AND METHODS}

Natural zeolitized volcanic tuffs were collected from Măcicaş area (Cluj County). The pyroclastic rocks belong to the Dej Tuff Complex, of a Badenian age and consist of volcanic tuffs and marly interlayers (Fig. 1a).

In the base of the tuffs' succession, yellowish to greyyellowish, coarse to medium granular sandstones occur. The tuffs are white-grayish in color and build-up a normally graded sequence (Fig. 1b). The volcanoclastic sequence begin with a compact, coarse grained, macroporous tuff (6 $\mathrm{m}$ thickness), with conchoidal fracture and a vacuolar texture. This level has been occasionally mined as raw material for constructions. It is followed by a 4-5 m thickness tuff level of volcanic tuff with a medium porosity and a conchoidal fracture. It is lighter in color than the first level. In the upper part of the volcanoclastic sequence, a fine grained, microporous, white-greenish in color tuff occurs. On its top, a yellowish clay level and the soil cover are present (Bedelean et al., 2004). Bulk rock samples were collected from the medium porous tuff level (labeled M1) and the macroporous tuff level (labeled M2), due to their relative homogeneous composition and structure.

\section{Petrographic investigations}

The petrographic observations were made by optical microscope (Zeiss AxioLab) on thin section. It was focused on the identification of the different mineralogical phases, on their quantification, and on the structural description of the material (Fig. 2, Table 1).

The chemical analyses of bulk rocks were performed at CEROC Cluj-Napoca using usual analytical methods for silicate materials. The identification of the minerals is completed by X-ray diffraction on random powder. The Xray diffractometer is a Siemens Bruker, $\mathrm{Cu} \mathrm{K \alpha}$ anticathode. The diffractograms are recorded from $10^{\circ}$ to $70^{\circ} 2 \theta$. The analytic conditions are $40 \mathrm{~A}, 40 \mathrm{kV}$, step of 2 degrees.
The specific surface area was measured using BET method on $0.2-0.4 \mathrm{~mm}$ crushed zeolitic tuff.

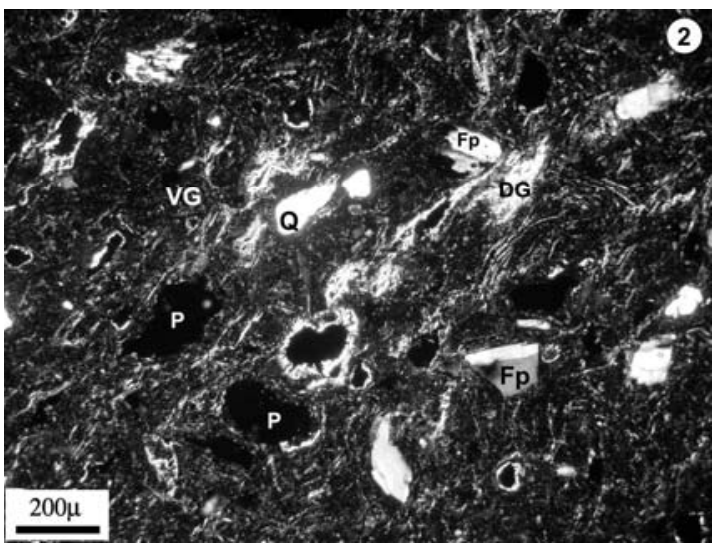

Fig. 2. Details of the vitric crystal tuff (sample M1) from Măcicaş, Cluj County, optic microscope, analyzed and polarized light: $Q=$ quartz; $F p=$ feldspar; $V G=$ volcanic glass; $D G=$ devitrified glass; $P=$ pores.

\section{Experimental ionic exchange process}

$\mathrm{NH}_{4}^{+}$removal was realized on two bulk samples Măcicaş 1 and Măcicaş 2 (Tables 1 and 2), grain size of 0.2$0.4 \mathrm{~mm}$, of the natural zeolite rich tuff from Măcicaş area. Each sample was chemically modified with $\mathrm{HCl} 1 \mathrm{M}(\mathrm{Z}-\mathrm{H}$ form) and $\mathrm{NaCl}+\mathrm{NaOH} 1 \mathrm{M} \mathrm{pH}=10$ (Z-Na form).

Adsorptive and ionic exchange properties of natural zeolites are determined by the structure of their crystalline network, which determine the channel system and also by the negative charge excess due to $\left[\mathrm{AlO}_{4}\right]^{5-}$ tetrahedrons compensated by mono- or divalent cations (e.g., $\mathrm{Na}^{+}, \mathrm{K}^{+}$, $\left.\mathrm{Ca}^{2+}, \mathrm{Mg}^{2+}\right)$. These counter ions are mobile and can be totally or partially exchanged during ionic exchange processes. The accurate measurement of the absorptive and ionic exchange capacities of the zeolitic tuff of Măcicaş induces a suitable preparation of the material.

The stages involved in the zeolite preparation are as follows: crushing, grinding, size separation, washing with distilled water, drying at $105^{\circ} \mathrm{C}$ for 6 hours, treatment with $\mathrm{HCl} 1 \mathrm{M}$ in a stirring reactor with a zeolite acid solution ratio of $1: 10$, washing with distilled water to $\mathrm{pH}=7$ and finally drying at $105^{\circ} \mathrm{C}$ for 6 hours. At the end of this sequence we obtained the zeolite in $-\mathrm{H}$ form $(\mathrm{Z}-\mathrm{H})$. Also, during the treatment with $\mathrm{HCl}$, zeolite channels are cleaned and pores opened (Cakicioglu-Ozkan and Ulku, 2005). To bring the zeolite in -Na form which proved to be more efficient in the ionic exchange process (Iovi et al., 1993; Mondale et al., 1995; Cobzaru et al., 2002), the zeolite is subjected subsequently to an alkaline treatment with strong $\mathrm{Na}^{+}$ solution $(\mathrm{NaCl} 1 \mathrm{M}$ solution brought to $\mathrm{pH}=10$ with a $\mathrm{NaOH} 1 \mathrm{M}$ solution) according to equation (1). After the alkaline treatment the zeolite samples are washed again with distilled water to $\mathrm{pH}=7$ and dried for 6 hours at $105^{\circ} \mathrm{C}$.

$$
\mathrm{Z}-\mathrm{H}+\mathrm{NaCl} \rightleftharpoons \mathrm{Z}-\mathrm{Na}+\mathrm{HCl}
$$

For the ionic exchange study we used a synthetic solution containing $\mathrm{NH}^{4+}$ ions $\left(0.0716 \mathrm{~g} / \mathrm{dm}^{3}\right)$ prepared from ammonium chloride (analytical purity reagent). Determination of ammonium ions in solution was realized using a Jenway spectrophotometer (Nestler solution, $420 \mathrm{~nm}$ ). Experiments were carried out without any modification of temperature and $\mathrm{pH}$ for the synthetic solutions. 
Table 1. Mineralogical composition of the zeolitic volcanic tuffs from Măcicaş (Cluj County) Legend: $Q=$ quartz; $F p=$ feldspar; $M=$ micas; $H b=$ hornblende; Lim = limonite; $C a l=$ Calcite; $M 1=$ medium porous tuff (median level); M2 = macroporous tuff (lower level).

\begin{tabular}{|c|c|c|c|c|c|c|}
\hline & \multicolumn{4}{|c|}{ Crystals } & \multirow{2}{*}{ Lithic fragments } & $\begin{array}{c}\text { Volcanic glass (secondary } \\
\text { minerals) }\end{array}$ \\
\cline { 2 - 6 } & $\boldsymbol{Q}$ & $\boldsymbol{F p}$ & $\boldsymbol{M}$ & Other & & $\sim 85 \%(70 \% \mathrm{zeolite})$ \\
\hline M1 & $2-4 \%$ & $4-5 \%$ & $5-6 \%$ & Cal, Lim & $<1 \%$ & $\sim 72 \%(60 \% \mathrm{zeolite})$ \\
\hline
\end{tabular}

Table 2. Chemical composition of the volcanic tuff from Măcicaş 1 and Măcicaş 2 samples (Cluj County). Analysis performed at CEROC Cluj-Napoca.

\begin{tabular}{|c|c|c|c|c|c|c|c|c|c|}
\hline Sample & $\begin{array}{c}\mathrm{SiO}_{2} \\
{[\%]}\end{array}$ & $\begin{array}{c}\mathbf{A l}_{2} \mathbf{O}_{3} \\
{[\%]}\end{array}$ & $\begin{array}{c}\mathbf{T i O}_{2} \\
{[\%]}\end{array}$ & $\begin{array}{c}\mathbf{F e}_{2} \mathbf{O}_{3} \\
{[\%]}\end{array}$ & $\begin{array}{c}\mathbf{C a O} \\
{[\%]}\end{array}$ & $\begin{array}{c}\mathbf{M g O} \\
{[\%]}\end{array}$ & $\begin{array}{c}\mathbf{N a}_{2} \mathbf{O} \\
{[\%]}\end{array}$ & $\begin{array}{c}\mathbf{K}_{2} \mathbf{O} \\
{[\%]}\end{array}$ & $\begin{array}{c}\mathbf{L O I} \\
{[\%]}\end{array}$ \\
\hline Măcicaş 1 & 63.98 & 14.53 & 0.35 & 1.71 & 5.46 & 0.23 & 1.00 & 0.88 & 11.86 \\
\hline Măcicaș 2 & 63.83 & 14.38 & 0.42 & 1.77 & 5.21 & 0.37 & 1.04 & 0.84 & 12.14 \\
\hline
\end{tabular}

The ionic exchange process were realized in a batch reactor in static regime using $10 \mathrm{~g}$ of the $0.2-0.4 \mathrm{~mm}$ grain size zeolitic tuff (Măcicaş 1 and Măcicaş 2) and $100 \mathrm{ml}$ ammonium ions solution (zeolite:solution $=1: 10$ ). Solution samples were collected every 24 hour for $\mathrm{NH}^{4+}$ concentration measurement until the equilibrium was reached.

We also worked in dynamic regime on a fixed bed column $\left(\mathrm{d}_{\mathrm{i}}=15 \mathrm{~mm}\right)$ containing $5 \mathrm{~g}$ of the $0.2-0.4 \mathrm{~mm}$ grain size zeolitic tuff with a flow rate of $0,055 \mathrm{ml} / \mathrm{s}$ for Măcicaş 1 and Măcicaş 2 samples. The $\mathrm{NH}^{4+}$ concentration of the inlet "fresh" solution is $0.0716 \mathrm{~g} / \mathrm{dm}^{3}$. Ammonium initial concentration of the synthetic solution was choose to be approximately forty times bigger than the concentration limit for $\mathrm{NH}^{4+}$ allowed to be discharged in surface waters according to Romanian legislation (HG188/2002; HG352/2005). Due to an increase of municipal wastewater quantities, after biological treatment in sewage treatment plants, ammonium concentrations can reach values up to 80 $\mathrm{mg} / \mathrm{dm}^{3}$.

The effluent $\mathrm{NH}^{4+}$ solution was collected at the outflow of the column every $50 \mathrm{ml}$ until the zeolitic tuff was exhausted. The $\mathrm{NH}^{4+}$ concentrations are measured for each $50 \mathrm{ml}$ successively sampled. The experiments were realized at room temperature $\left(20^{\circ} \mathrm{C}\right)$. The ionic exchange reaction, prevailing in our zeolitic tuff system, is the $\mathrm{Na}$ zeolite to $\mathrm{NH}_{4}$ zeolite conversion:

$$
\mathrm{Z}-\mathrm{Na}+\mathrm{NH}_{4}^{+} \rightleftharpoons \mathrm{Z}-\mathrm{NH}_{4}+\mathrm{Na}^{+}
$$

The results obtained for the two samples, Măcicaş 1 and Măcicaş 2, are presented for static and dynamic regimes, respectively.

\section{RESULTS}

\section{Petrographic results}

The volcanic tuffs from the study area generally have a vitroclastic and vitric crystal texture and are zeolitized. They consist of $70-85 \%$ of volcanic glass, $15-25 \%$ of crystals and lithic fragments in subordinate amounts (2-3\%; Table 1).

The main component is represented by volcanic glass as fragments with angular edges (glass shards). The primary magmatic minerals include K-feldspars and plagioclases, quartz, micas, amphiboles and opaque minerals - Fe-oxides and sulphides (Fig. 2). Lithic fragments are represented by sedimentary, magmatic and metamorphic rock fragments.

The alteration features are observable under great magnifications. They consist in disseminated crystallization of clay minerals in replacement of primary phases as biotite (plate) and in an advanced degree of devitrification, the glass shards being significantly replaced by zeolite minerals, which consist mainly of clinoptilolite (Fig. 3). These zeolites are present as micron- and submicron-sized crystals replacing the glass matrix, or as larger crystals in the pores or voids.

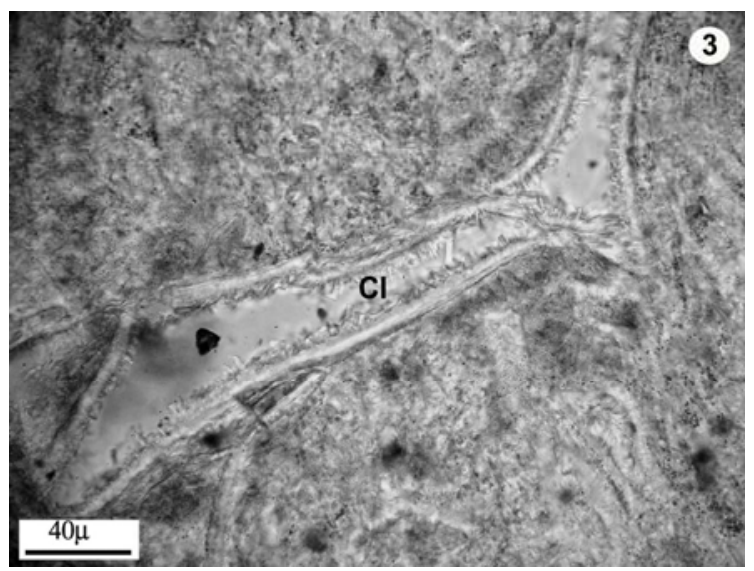

Fig. 3. Pseudomorphic replacement of a glass shard by zeolites (clinoptilolite); sample M1, vitric crystal tuff, Măcicaş, Cluj County, $\mathrm{IN}$; optic microscope, $\mathrm{Cl}=$ clinoptilolite.

The zeolite crystals are about 2-10 microns in size; rarely are they larger (40-50 microns). The X-ray diffraction diagrams performed on random powder of the whole material indicated the massive presence of a main zeolite species, i.e., clinoptilolite and subordinately mordenite (Fig. 4). The semi-quantitative estimation from the X-ray diffractograms indicates that the zeolites reached between $60 \%$ and $70 \%$ from the crystallized fractions of the tuff. The quantity of zeolite appears slightly superior in the macroporous tuff from the lower level than in the medium porous tuff from the medium level. According to the microscope observation, the other minerals identified are quartz, feldspar, montmorillonite, and illite.

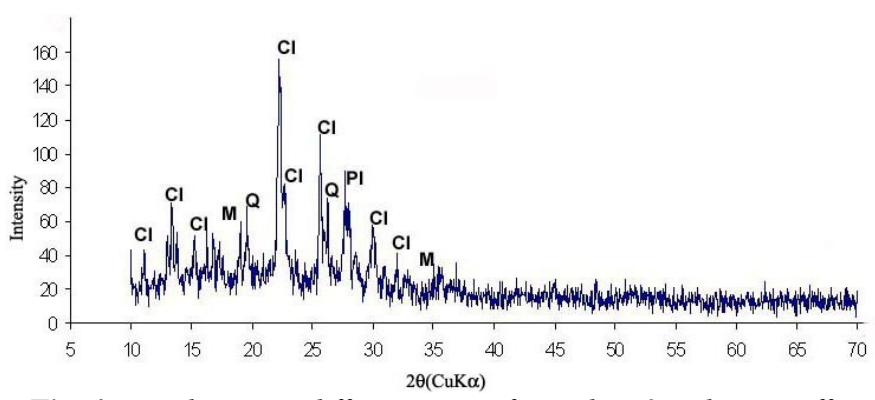

Fig. 4. Powder X-ray diffractogram of sample M2, volcanic tuff from Măcicaş, Cluj County. $\mathrm{Cl}=$ clinoptilolite, $\mathrm{Pl}=$ plagioclase; $Q=$ quartz; $M=$ montmorillonite. 
The bulk chemical analyses performed on tuff samples are presented in Table 2 . The high quantity of secondary and hydrated material (zeolite and smectitic clay minerals) is indicated by the high values of L.O.I. (11.86 and 12.14). Considering an average $15 \%$ L.O.I. of the zeolites (dominant clinoptilolite) the amount of this mineral in the two samples may be estimated around $70-80 \%$.

The measured specific area is $27.40 \mathrm{~m}^{2} / \mathrm{g}$ for the medium porous volcanic tuff (Măcicaş 1) in the median part of the succession from Măcicaş, and respectively $21.42 \mathrm{~m}^{2} / \mathrm{g}$ for the macroporous tuff sample (Măcicaş 2).

\section{Experimental results}

In static regime, the evolution of the $\mathrm{NH}^{4+}$ ion concentration present similar decrease with time of reaction for the two samples M1-Na and M2-Na (Fig. 5). The $\mathrm{NH}^{4+}$ ion concentration drastiquely drop from the initial 0.0716 $\mathrm{g} / \mathrm{dm}^{3}$ down to about $0.003-0.006 \mathrm{~g} / \mathrm{dm}^{3}$ during the first 20 hours. For both samples, ionic exchange efficiency reached $100 \%$ faced to the initial $0.0716 \mathrm{~g} / \mathrm{dm}^{3} \mathrm{NH}^{4+}$ concentration. The equilibrium, in both cases, was reached after 96 hours.

The ionic exchange reactions took place for both samples considered (ammonium concentration in water decreased); therefore the zeolites under study are considered to be active in the ionic exchange process.

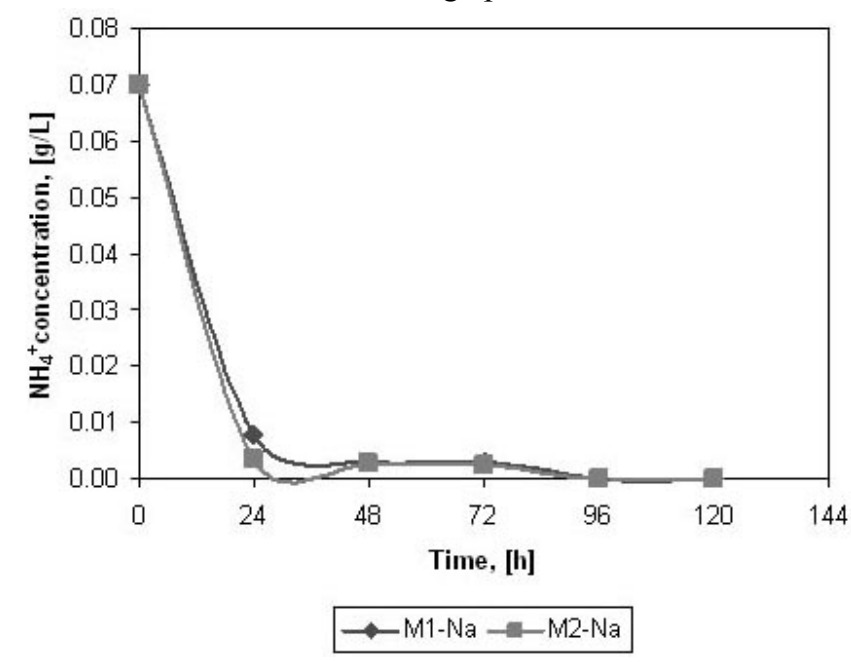

Fig. 5. Evolutions of the $\mathrm{NH}_{4}{ }^{+}$concentrations of the initial $0.0716 \mathrm{~g} / \mathrm{dm}^{3} \mathrm{NH}_{4}^{+}$solution versus time during the adsorption experiment in static regime for the Măcicaş 1 and Măcicaş 2 samples in -Na form.

In dynamic regime the $\mathrm{NH}^{4+}$ concentrations of the reacted solutions sampled at successive steps, every $50 \mathrm{ml}$ at the outflow of the column, indicate parallel evolution of the $\mathrm{NH}_{4}{ }^{+}$concentrations for the two samples. The efficiency of the ionic exchange process was calculated to be $100 \%$ for both samples.

The ammonium ions were completely removed after 50 ml solution passed on M1-Na sample and M2-Na sample (Fig. 6).

The evolution of the $\mathrm{NH}^{4+}$ concentrations in the reacted outflow solution versus the increase of volume of the reacted solution indicates two successive stages in the phenomenon (Fig. 6):

(a) a complete adsorption of the $\mathrm{NH}^{4+}$ ions from the solution onto the zeoltic material during the first stage

(b) a progressive increase of the $\mathrm{NH}^{4+}$ ions in solution in the second stage which is a consequence of a decrease of the quantity and absorption rate of the $\mathrm{NH}^{4+}$ ions onto the zeolitic material.

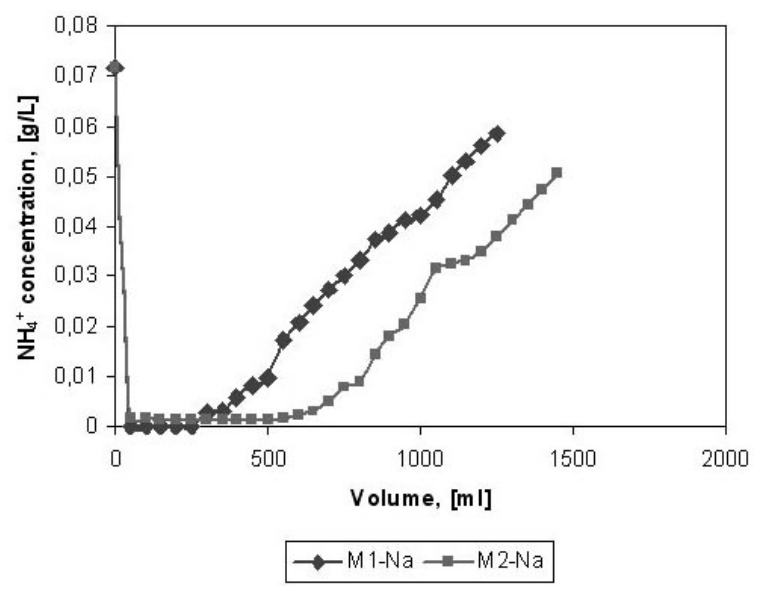

Fig. 6. Evolutions of the $\mathrm{NH}_{4}{ }^{+}$concentrations of the initial $0.0716 \mathrm{~g} / \mathrm{dm}^{3} \mathrm{NH}_{4}^{+}$solution versus volume of reacted solution during the adsorption experiment in dynamic regime for the Măcicaş 1 and Măcicaş 2 samples in-Na form.

For M1-Na and M2-Na samples, the first stage operates from the beginning of the experiment to volumes of outlet solutions of 250 and $500 \mathrm{ml}$ respectively. In the second stage of the experiment the two samples M1-Na and M2-Na show linear increase of $\mathrm{NH}^{4+}$ concentrations versus volume with similar slopes (Fig. 6). As the zeolite content in the two tuff samples is similar, the differences in the exchange process under dynamic regime could be due to differences regarding the absorbers' specific area, which is higher for the M1 (medium porous) tuff sample.

\section{DISCUSSIONS AND CONCLUSIONS}

The volcanic tuffs from Transylvanian Basin were generated during the explosive stage of the Tertiary volcanism. They are associated with the sedimentary deposits of a mainly detrital nature (Mârza et al., 1991). The tuffs formed due to the cementation of the explosive products of the acidic and subordinately intermediary character.

The process of zeolitization, of a halmyrolitic sin- and diagenetic nature, took place in a marine, alkaline environment at a $\mathrm{pH}$ between 9.5-9.8. Mainly the volcanic glass was substituted by zeolites, due to its high instability in the marine environment.

Zeolites formed as a result of the reaction between water and solid matter, especially represented by volcanic glass. The resulted zeolitic species were dependent on temperature, pressure and the variable chemical parameters: Si:Al ratio, $\mathrm{Ca}^{2+}, \mathrm{Na}^{+}$, and $\mathrm{K}^{+}$ratios and the pressuredependent $\mathrm{H}_{2} \mathrm{O}\left(P_{\mathrm{H} 2 \mathrm{O}}\right)$ and $\mathrm{CO}_{2}\left(P_{\mathrm{CO} 2}\right)$ activities (Bedelean and Stoici, 1984). Devitrification of volcanic glass and zeolite formation represented ubiquitous anadiagenetic processes in the tuff levels.

The amount of zeolites is directly correlated to the original amount of volcanic glass. Thus, the zeolite-richest levels are represented by the vitric tuffs, and respectively medium- and fine-grained vitric crystal ones. The main zeolite species identified by optical microscopy and X-ray diffraction is clinoptilolite. The petrographic and chemical analyses of the vitric tuff from Măcicaş suggest amounts of 
zeolite which can reach $60-70 \%$ of the rock. The high porosity of the tuffs argues to an almost homogeneous distribution of the zeolitic alteration through the tuff formation.

The absorption experiments in static and dynamic regime demonstrate the high adsorptive quality of the material. In the static experimental conditions of $0.0716 \mathrm{~g} / \mathrm{dm}^{3} \mathrm{NH}^{4+}$ solution versus $10 \mathrm{~g}$ of crushed zeolitic tuff, the ammonium ions were almost completely removed in 24 hours. In dynamic experiments $0.0716 \mathrm{~g} / \mathrm{dm}^{3} \mathrm{NH}^{4+}$ solution flowing through $5 \mathrm{~g}$ of crushed zeolitic tuff), 250 and $500 \mathrm{ml}$ of solution have been completely depleted in $\mathrm{NH}^{4+}$ ion for M1-Na and M2-Na respectively before residual of $\mathrm{NH}^{4+}$ have been measured in the reacted solution. The absorption efficiency of the $5 \mathrm{mg}$ of zeolitic tuff in dynamic experiment is demonstrated up to $1400-1500 \mathrm{ml}$ of reacted solution.

As a conclusion, the secondary minerals developed in the volcanic tuff from Măcicaş region is mainly represented by zeolites, among which clinoptilolite dominates. This is a general statement for most of the tuff occurrences in Cluj County, for the cases when the devitrification of volcanic glass reached an advanced stage. The zeolitic tuffs of Măcicaş region show large specific surface area associated to their high zeolite contents. These characteristics provide sufficient absorption capacities to be used in industrial wastewater treatment. The $\mathrm{NH}^{4+}$ ionic exchange process on zeolitic volcanic tuffs from Măcicaş area can be used as a finishing stage (after the biological process) in wastewater treatment plants in order to assure compliance with environmental standards. After the ionic exchange process takes place, the zeolite samples in $\mathrm{Z}-\mathrm{NH}_{4}$ form can be regenerated and reused in the same process or can be used as fertilizer. Another practical side is the homogeneous characteristic of the zeolitic tuff deposit which is favorable to the industrial mining.

Acknowledgments. This material is based upon a work supported by CNCSIS grant 1745 .

\section{R E F E R E N C E S}

Baykal Beler, B. 1998, Clinoptilolite and multipurpose filters for upgrading effluent ammonia quality under peak loads. Water Science and Technology, 37 (9): 235-242.

Baykal Beler, B., Guven, D.A. 1998, Performance of clinoptilolite alone and in combination with sand filters for the removal of ammonia peaks from domestic wastewater. Water Science and Technology, 35 (7): 47-54.

Bedelean, H., Stanca, M., Măicănean, A., Burcă, S. \& Dulămiță, N. 2004, Characterization of zeolitic volcanic tuffs from Măcicaş area (Cluj County). Analele Universității din Oradea, fascicula Chimie, XI: 67-72.

Bedelean, I., Stoici, S. 1984, Zeoliții. Ed. Tehnică, Bucureşti, 227 pp.

Bish, D.L., Boak, J.M. 2001, Clinoptilolite-Heulandite Nomenclature. In Reviews in Mineralogy and Geochemistry, Natural Zeolites, Occurrence, Properties, Applications (Bish, D.L., Ming, D.W., Eds.), 45: 207-217.

Buss, S.R., Herbert, A.W., Morgan, P., Thornton, S.F. \& Smith, J.W.N. 2004, A review of ammonium attenuation in soil and groundwater. Quarterly Journal of Engineering, Geology and Hydrogeology, 37: 247-359.
Cakicioglu-Ozkan, F., Ulku, S. 2005, The effect of $\mathrm{HCl}$ treatment on water vapor adsorption characteristics of clinoptilolite rich natural zeolite. Microporous and Mesoporous Materials, 77: 47-53.

Cerri, G., Langella, A., Pansini, M. \& Cappelletti, P. 2002, Methods of Determining Cation Exchange Capacities for Clinoptilolite-rich Rocks of the Logudoro Region in Northern Sardinia, Italy. Clays and Clay Minerals, 50 (1): 127-135.

Cobzaru, C., Oprea, S., Hulea, T., Hulea, V. \& Dumitriu, E. 2002, Aplicații ale zeoliților naturali în eliminarea metalelor din apele uzate şi catalizarea unor reacții chimice organice. Revista de Chimie, 53 (10): 674-677.

Colella, C. 1996, Ion exchange equilibria in zeolite minerals. Mineralium Deposita, 31: 554-562.

Coombs, D.S., Alberti, A., Armbruster, T., Artioli, G., Colella, C., Galli, E., Grice, J.D., Liebau, F., Mandarino, J.A., Minato, H., Nickel, E.H., Passaglia, E., Peacor, D.R., Quartieri, S., Rinaldi, R., Ross, M., Sheppard, R.A., Tillmanns, E., \& Vezzalini, G. 1997, Recommended nomenclature for zeolite minerals: report of the subcommittee on zeolites of the International Mineralogical Association, Commission on New Minerals and Mineral Names. The Canadian Mineralogist 35: 1571-1606.

Englert, A.H., Rubio, J. 2005, Characterization and environmental application of a Chilean natural zeolite. International Journal of Mineral Processing, 75 (1-2): 2129.

Farkas, A., Rozic, M. \& Barbaric-Mikocevic, Z. 2005, Ammonium exchange in leakage waters of waste dumps using natural zeolite from the Krapina region, Croatia. Journal of Hazardous Materials, 117 (1): 25-33.

Hay, L.R., Sheppard, A.R. 2001, Occurrence of Zeolites in Sedimentary Rocks: An Overview. In Reviews in Mineralogy and Geochemistry, Natural Zeolites, Occurrence, Properties, Applications (Bish, D.L., Ming, D.W., Eds.), 45: 217-234.

Iovi, A., Burtică, G. \& Pode, R. 1993, Studies concerning the natural native zeolites. Chemical Bulletin Technical University of Timişoara, 38 (52): 29-37.

Jorgensen, T.C., Weatherley, L.R. 2003, Ammonia removal from wastewater by ion exchange in the presence of organic contaminants. Water Res., 37 (8): 1723-1728.

Kazantseva, L.K., Belitsky, I.A. \& Fursenko, B.A. 1997, Zeolite-Containing Rocks as Raw Material for Sibeerfoam Production. In Natural Zeolites - Sofia '95 (Kirov, G., Filizova, L. \& Petrov, O., Eds.). Sofia: Pensoft Publishers, 33-42.

Langella, A., Pansini, M., Cappelletti, P., de Gennaro, B., de Gennaro, M. \& Colella, C. $2000, \mathrm{NH}_{4}^{+}, \mathrm{Cu}^{2+}, \mathrm{Zn}^{2+}, \mathrm{Cd}^{2+}$ and $\mathrm{Pb}^{2+}$ exchange for $\mathrm{Na}^{+}$in a sedimentary clinoptilolite, North Sardinia, Italy. Microporous and Mesoporous Materials, 37 (3): 337-343.

Levya-Ramos, R., Aguilar-Armenta, G., GonzalesGutierrez, L.V., Guerrero-Coronado, R.M. \& MendozaBarron, J. 2004, Ammonia exchange on clinoptilolite from mineral deposits located in Mexico. Journal of Chemical Technology \& Biotechnology, 79 (6): 651-657.

Mârza, I., Codoreanu, F., Hosu, A., Plăceanu, M.L., Marian, D., Pop, R. \& Tămaş, D. 1991, Caractérisation pétrographique synthétique des tufs volcaniques de la région Dej-Cluj-Napoca et signification volcanologique. 
The Volcanic Tuffs from the Transylvanian Basin, Romania, Cluj-Napoca, 171-181

Meszaros, N., Nicorici, E. (Eds.) 1976, Pe poteci cu bănuței de piatră, Sport-Turism, Bucureşti, $190 \mathrm{pp}$.

Mondale, K.D., Carland, R.M. \& Aplan, F.F. 1995, The comparative ion exchange capacities of natural sedimentary and synthetic zeolites. Minerals Engineering, 8 (4-5): 535-548.

Mumpton, F.A. 1996, The natural zeolite story. In Proceedings of the $3^{\text {rd }}$ National Congress - AIMAT, omaggio scientifico a Riccardo Sersale (Colella, C., Ed.), Napoli: De Frede, 31-64.

Pansini, M. 1996, Natural zeolites as cation exchangers for environmental protection. Mineralium Deposita, 31: 563575.

Park, J.-B., Lee, S.-H., Lee, J.-W. \& Lee, C.-Y. 2002, Lab scale experiments for permeable reactive barriers against contaminated groundwater with ammonium and heavy metals using clinoptilolite. Journal of Hazardous Materials, 95 (1-2): 65-79.

Perić, J., Trgo, M. \& Vukojević Medvidović, N. 2004, Removal of zinc, copper and lead by natural zeolite-a comparison of adsorption isotherms. Water Research, 38: 1893-1899.

Răcătăianu, P., Petruț, G. \& Mogoş, P.A. 1991, The Volcanic Zeolitic Tuffs North of Cluj-Napoca and Their Economic Utility. The Volcanic Tuffs from the Transylvanian Basin, Romania, Cluj-Napoca, 311-315.

Sarioglu, M. 2005, Removal of ammonium from municipal wastewater using natural Turkish (Dogantepe) zeolite. Separation and Purification Technology, 41 (1): 1-11.

Weatherley, L.R., Miladinovic, N.D. 2004, Comparison of the ion exchange uptake of ammonium ion onto New Zeeland clinoptilolite and mordenite. Water Research, 38 (20): 4305-4312. 